\title{
Maoist Conflict, Community Forestry and Livelihoods: Pro-poor Innovations in Forest Management in Nepal
}

\author{
Nirmal K B.K.*, Ravi K Shrestha*, Sudil G Acharya* and Abdul S Ansari* \\ * Livelihoods \& Forestry Programme (LFP), Nepal \\ Corresponding author: N-BK@lfpeast.org.np
}

\begin{abstract}
Violent conflicts are quite often perceived as a destructive and negative phenomenon, and there is little understanding of how they also offer opportunities for a positive change in the society. In particular, little is understood about how violent conflicts and development processes interact and create positive changes in local institutions and practices. This article focuses on such interactions observed amongst the Community Forest User Groups (CFUGs) in the Koshi Hills of Nepal, as the Livelihoods and Forestry Programme (LFP) worked through the conflict period. It demonstrates that the Maoist conflict contributed in several ways to enhance the pro-poor outcomes of development actions. We show that the conflict helped empower the marginalised groups, improve their access to community resources, and bring about important changes within the local institutions and practices, contributing to equitable resource management. We suggest that there are positive sides of a violent conflict, where development interventions need to focus on. We also argue that development brings about equitable outcomes if it is complemented with local level advocacy in favour of the poor and marginalised groups.
\end{abstract}

Key words: community forestry, conflict, livelihoods, social inclusion, development

\section{INTRODUCTION}

In academic discourse and common parlance, a debate is ongoing as to whether violent conflicts play a constructive or a destructive role in the development process. On the constructive side, conflicts are considered a major cause of destruction of old socio-economic structures and processes that are often discriminatory and exploitative (Karki and Seddon 2003). In Nepal, an age-old proverb reads, "Unless you demolish the old house, you cannot build a new one." On the destructive side, the argument is that destruction hinders development and adds to its cost, which can be very painful for a poor country like Nepal (ibid).

Building on the authors' experience and reflections of working with the Community Forest User Groups (CFUGs) in four districts (viz. Dhankuta, Terhathum, Sankhuwasabha and Bhojpur) in the Koshi Hills of Nepal and Livelihoods and Forestry Programme's (LFP) monitoring system, this article challenges this dichotomy in the context of decade-old (19962006) Maoist insurgency. We demonstrate that despite its negative impact on development in general and on the technical aspect of community forest management in particular, the Maoist conflict has in several ways generated pressures for pro-poor change in the CFUGs. We further show that the interactions between the local political movements, armed conflict and development interventions have enhanced the access of the poor and historically excluded sections to community forest resources. These changes were possible with the increase in the voice and influence of the poor and the excluded into the processes of Community Forestry (CF), and were institutionalised into CFUGs' policies and practices. These served as conflict coping strategies at the CFUG level and created a favourable environment for the post-conflict development work.

\section{CONTEXT}

In Nepal, the State and the Maoist insurgents were engaged in an armed conflict during 1996 to 2006. The conflict tremendously affected everyday life of the people and country's overall development leading to a significant decline in state services, including forestry services (Banjade and Timsina 2005). The government was unable to collect revenue as planned and to achieve its development targets (NPC 2007). 
The rural people, especially those who lived in and around the forests and depended on forest resources for their livelihoods, became the immediate victims of the conflict. While almost all sections of society became highly vulnerable to the conflict, it exerted pressure for empowering those communities that were historically marginalised and had little access to development interventions.

During the conflict, the CFUGs came under tremendous pressure from the warring sides, viz. the State security forces (army and police) and the Maoist insurgents (Uprety 2006). The conflict affected the way forest was protected and used, and on the CF processes from macro to micro level. During the conflict, the forest evoked fear in rural areas. Security forces considered it a place where the insurgents trained and hid, laid ambushes, or hid their arms and ammunition. Therefore, in some areas, security forces cleared forests in order to gain a clear view of their enemies. In many cases, they prohibited entry of locals into the forest (Uprety 2006). Such prohibitions were even applied to the staffs of the District Forest Office (DFO) and LFP, which, as a result, restricted such tasks as inventory, forest management interventions, and forest-based income-generating activities. However, it also reduced illegal killing and poaching of wild animals and logging of timber, which led to the conservation of wildlife species and biodiversity.

Currently, a total 1,396 CFUGs have been formed in the Koshi Hills. They manage 110,952 ha (82 percent of the potential CF area) of forest and benefit 131,522 households. Among the households, approximately 50 percent are poor. The area is a mosaic of many different ethnic and caste groups, though historically, the area was inhabited mainly by Rai and Limbu ethnic groups. These communities had their indigenous land tenure system, viz. Kipat ${ }^{7}$ system, the lands under kiput were nationalised in 1961. These communities have been opposing state ownership of their land, including forests, and, in some places like Sankhuwasabha and Bhojpur, have been demanding return of forest as indigenous system of kipat. Different wings of the Maoist Party, particularly Limbuwan and Khumbuwan Mukti Morcha (Liberation Front), had raised this issue during the conflict.

In the Koshi Hills, the Maoists destroyed twelve range post offices, and many forestry staffs shifted to district level offices. The Maoists claimed that they were running the new regime (naya satta) with their Janasarkar (People's Government) established at district and village level. They also declared the area as a Limbuwan state. In some sites, the local Maoist governments had made provision for using and managing forest resources. During the conflict, both the government security forces and Maoists warned people not to organise general assemblies or gatherings within which major decisions would be made.

The forestry programme in the area was launched based on the forestry policy of the Government of Nepal (GoN). The DFO has been supporting community forestry, leasehold forestry, private forestry and governmentmanaged forest management regimes in the area. The LFP has been supporting DFOs and civil society organisations since 2001 in order to reduce vulnerability and improve the livelihoods of the rural poor through equitable, efficient and sustainable use of forest resources. It mobilises the people through its animation programme, supports the DFOs on forest management interventions, and has introduced collaboration and coordination mechanisms. Accordingly, different strategies have been prepared in line with the government policy. Pro-poor and Social Inclusion Strategy (PPSIS) is the key strategy to work with and for the poor and excluded members of user groups. Safe and Effective Development in Conflict (SEDC) was another strategy to work in conflict situations. These strategies were mainstreamed in the planning, implementation and monitoring of the programme.

\section{CONCEPTUAL FRAMEWORK OF STUDY}

The Livelihoods and Social Inclusion (LSI) monitoring framework, developed by the DFID 
in 1990, has been employed to prepare this paper. This framework has been intensively used within the LFP for planning and monitoring of the interventions. It examines three key areas. First, it looks at the access of the poor and excluded to assets or resources, especially to the management and utilisation of local resources (forest, fund, barren land, or infrastructure). Second, it examines the change in policy and institutions of groups, i.e. how the CFUG rules are changing and formalised through decision-making and documentation in their constitutions and operational plans (OPs). And finally, the framework looks at strengthening of the voice and influence of the poor and excluded in the groups, especially at how they are organised, their collective voices are raised and made influential in the decisionmaking, and how benefit-sharing takes place for their good. This article examines the impact of the violent conflict on each of these three dimensions.

\section{THE IMPACT OF THE CONFLICT VIS-À-VIS LIVELIHOODS AND FORESTRY PROGRAMME INTERVENTIONS}

We present below our findings on the impact of the violent (and armed) Maoist conflict on voices and influences, changes in policies and institutions, and innovations in access to assets.

\section{Increase in Voice and Influence}

There are different ways in which the violent conflict has added positively on LFP initiated support that empowers the poor and excluded to articulate their voices. Particularly the Maoists empowered such groups and encouraged them to escape from fatalistic attitude of community development. They also started to challenge the traditional leaderships of the CFUGs. Earlier, the CF was considered a chairperson's forestry as the domination of chairperson was significant, but now it is considered as users' forestry as the CFUG members started to take up the forest management rights. The insurgents focused on the rights of all the members over common property, rather than on private control of such property. As a result, the access of all households, including the poor and excluded, to the forest increased. In some cases, the poor and excluded manipulated their own aspirations as the voice of the Maoists and created the pressure for pro-poor changes. As the insurgents took shelter mostly at the houses of these people, the elite members became sensitive to their voice. The poor and excluded participated in CFUG processes to a much greater extent, became involved in decisionmaking processes, and assumed leadership roles. Even the village elites encouraged the poor and excluded to put forward their agenda for wider discussion. Some CFUGs also made provisions in their rules for giving priority to the agendas of women and dalits. Table 1 shows the percentage increase in the participation of women and poor in CFUG committees during the period.

Table 1: Percentage Change in the Participation of the Poor and Excluded in Decision-Making Forums in the Koshi Hills

\begin{tabular}{|c|l|l|l|}
\hline SN & Forum & 2002 & 2007 \\
\hline 1. & Participation of women in CFUG committees & 19 & 35 \\
\hline 2. & Participation of women in CFUG assembly & 18 & 30 \\
\hline 3. & Participation of poor in CFUG committees & NA & 50 \\
\hline 4. & Participation of poor in CFUG assembly & NA & 60 \\
\hline 5. & Participation of dalits in CFUG committees & 3 & 8 \\
\hline 6. & Participation of dalits in CFUG assembly & 2 & 9 \\
\hline
\end{tabular}
Note: NA: Not Available 
Generally CFUG assemblies were prevented during the conflict. The Maoists threatened that if CFUG assemblies or meetings were held, it would amount to supporting the old regime. In addition, it was very difficult to mobilise rural people because both the Nepalese Army and the Maoists would blame service providers of misguiding the rural people. During the conflict, women and poor members of CFUGs led the groups and conducted assemblies and meetings. None of the ten CFUGs in Budhbare VDC of Dhankuta district held an assembly for five years. Later, however, the women of Bhanta CFUG led and conducted an assembly by negotiating with the local leaders of the Maoist Party. Then other CFUGs followed the same strategy.

The strategy of the LFP and its partners of using elites as a channel to reach the poor became easier due to the conflict, as the Maoists were also raising the similar concerns at the grassroot level. According to the chairperson of a CFUG in Dhankuta, their fund was mobilised as revolving fund for income-generating activities for the poor and this provision was introduced in their Constitution. Many neighbouring CFUGs (e.g. Banpala and Midure CFUGs) gradually adopted the same practice. Now, the poor know what provisions are there in their favour. The supporters or sympathisers of the Maoists were also engaged in CFUGs processes in one way or other and they understood that the CF is bringing good ideas for the poor and excluded. The Maoist insurgents started to support the proper utilisation of the CFUG fund and monitoring of the CFUG activities. Also, the local elite or traditional leaders became more responsive toward the poor and excluded. They realised the need for supporting these groups and wanted to cope up with their own livelihood and security challenges in the difficult situation.

\section{Change in Policy and Institutions}

Some of the major rules of CF were amended due to the influence of LFP intervention and the Maoists. The new provisions made in the CFUGs' constitution and OPs include inclusive membership; proportionate representation in CFUG committees, equitable benefit-sharing mechanism, public auditing of resources and information, and resource allocation for the poor and excluded. Transparency of resource utilisation and decision-making processes were the major issues raised by the Maoists in the functioning of CFUGs. In order to introduce a transparent system, CFUGs started and institutionalised the public auditing and the mechanisms of information-sharing and intensive discussion amongst the members. Earlier, CFUG constitutions and OPs used to be prepared by the DFO staff in consultation with CFUG committee, but now detailed discussions are carried out amongst the members. Table 2 shows that CFUGs have institutionalised the rules that can address the issues of conflicting parties.

\section{Table 2: Percentage of CFUGs having Institutionalised Equity Oriented Activities in the Koshi Hills}

\begin{tabular}{|l|l|l|}
\hline SN & Activities & $\%$ of CFUGs \\
\hline 1. & Equitable forest product distribution & $26 \%$ \\
\hline 2. & $\begin{array}{l}\text { Constitution with at least 3 equitable provisions: } \\
\text { - Income-generating activities for the poor and excluded } \\
\text { - Participation in committee } \\
\text { - Fee reduction in forest products }\end{array}$ & $62 \%$ \\
\hline 3. & CFUGs practising public audit & $50 \%$ \\
\hline 4. & $\begin{array}{l}\text { OP/Constitution of CFUGs - more inclusive and equitable provision } \\
\text { in favour of the poor and excluded groups }\end{array}$ & $80 \%$ \\
\hline
\end{tabular}


Certain CFUG activities, such as the mobilisation of the fund for income-generating activities for the poor, became a success, and the Maoists and target groups themselves accepted them. The CFUGs then institutionalised these practices by incorporating in their constitutions and OPs. Now, 80 per cent of the CFUGs have stipulated pro-poor activities in their documents. Though CFUGs initiated such activities out of Maoist pressure initially, they have become further convinced once these became successful and popular in the local and district levels. This has encouraged the rural elites to adapt pro-poor development strategy at the local level.

Membership exclusion was one of the major issues in CF. It became an issue because the poor and excluded did not get the membership of CFUGs., In Parbat district (outside the Koshi Hills), a total of 996 households were excluded from the CFUGs, even though these were traditional users and were interested to become the members. About 80 per cent of them were from the poor categories. They were charged higher fees to become the member, for which the poor could not afford. In some cases, the poor requested local Maoists to intervene the CFUGs and in others they joined the Maoist Party and ultimately joined the CFUG. In Ratamate CFUG in Bhojpur District, for instance, twenty-four dalit households entered the CFUG by waiving the entry fee under the Maoist pressure.

The process of representation of women, dalits, poor and janajatis in decision-making forums was institutionalised and strengthened with the Maoist influence at the CFUG level. During the conflict, some CFUGs that lacked the representation of such people hurriedly nominated a few from them and then introduced such provisions in the constitution after the assembly decision. The provision of proportionate representation has been institutionalised in the constitutions of most CFUGs. The participation of the marginalised and dalits in leadership positions has notably increased. This has changed the earlier representational basis, which was based on tole (hamlet), toward a representation based on caste, gender and wealth-rank group. Also, men and women are being considered as household heads of CFUGs because the percentage of single women has increased due to the conflict. The benefit-sharing mechanism has become more equitable partly due to the direct facilitation of LFP and partly due to the indirect threat of Maoists. About 62 per cent of the CFUGs have made provision of equitable benefit-sharing mechanism in the Koshi Hills (Table 2). They provide forest products on free of cost to the poor members. CFUGs have also made provisions of having different forest products prices for different wellbeing categories.

\section{Innovations in Access to Assets}

The conflict has enhanced the access of the poor and excluded to the internal and external resources of the CFUGs. There have been improvements in the access of such groups to CFUGs' fund and its mobilisation for pro-poor small infrastructure, income-generating activities, and human capital development (training opportunities). The conflict also improved the reach of the poor and excluded to natural resources and forest products, and the utilisation of barren land for conducting income-generating activities. During the conflict, the focus of the LFP was on mobilising the CFUGs' resources for the benefit of the poor and excluded and it was coincidently supported by the Maoists. Therefore, there are four main ways in which the conflict and the LFP support together created conditions for the equitable utilisation of CFUG funds for pro-poor activities. First, the CFUG elites, with the LFP's pro-poor sensitisation process and under Maoist pressure, decided to invest CFUG funds to support pro-poor activities. LFP has launched activities such as revolving fund for income generation, allocation of community forest land to the poor, and the establishment of small and medium enterprises. However, it was difficult to mobilise matching CFUG funds, as these were in the hands of either local elites or were kept in banks. The Maoists threatened those who had captured such funds and started to collect such funds as 'donation'. To avoid such donation, the 
CFUG committees mobilised the funds for the benefit of the poor. They provided the funds to match against the LFP initiated activities, such as revolving fund or investment in the activities that benefit the poor quickly. Table 3 shows that, in 2001, CFUGs expended only 3 per cent of their funds on pro-poor activities, but it increased to 28 per cent by 2007 . For instance, Rajendra Khadka, vice- chairperson of Pahalmane CFUG of Kurule VDC in Dhankuta, says that local Maoist leaders demanded donation of NRs 50,000 from the CFUG fund. However, the CFUG provided loans (NRs 32,000 ) to sixteen poor households for initiating income-generating activities. The Maoists demanded money again, but the CFUG provided loans (NRs 10,000) to four other households. Then the Maoist stopped demanding such donations. The CFUGs also planned other pro-poor provisions (e.g. allowances for poor committee members, scholarships for poor students) in order to save their money from donating to Maoist.

Second, the elite members of the CFUGs, under pressure from the Maoists, reduced the interest rate on group loans to the poor. The CFUG office-bearers were local moneylenders who exploited the poor by lending at rates as high as 24 to 36 per cent. The Maoists were not happy with the individual lending and high interest rates and accused the moneylenders of exploiting the poor. Now, the poor are provided loans from the CFUG funds at the interest rate of 6 to 12 per cent, as LFP has provided to run and sustain the revolving fund in the CFUG.

Third, CFUGs not only diverted their funds towards the poor but also started

making investments from unproductive to productive sectors of infrastructure development. For example, a high proportion of the funds was spent on constructing temples, where dalits were not allowed to enter. But more recently, major share of the community development fund are used in small infrastructure in the needy part of the villages.

Lastly, the pro-poor intervention of LFP at the time of the conflict enhanced the access of the poor to the CF processes. Many CFUGs in the LFP working areas have allocated the barren forest land to the poor to carry out income generating activities. However, given the nature of forestry programme, it takes time to benefit the users and therefore LFP has started the quick impact activities that include drinking water, feeder road construction, small-scale irrigation systems, and small-scale incomegenerating activities. These activities were accepted by all the stakeholders at the local level.

Table 3: Change in CFUG fund mobilisation for pro-poor activities

\begin{tabular}{|l|r|r|r|}
\hline Income or expenditure (NRs.) & $\mathbf{2 0 0 1}$ & \multicolumn{1}{c|}{$\mathbf{2 0 0 7}$} & \multicolumn{1}{c|}{ Difference } \\
\hline Total income & $4,967,117.63$ & $32,102,874.55$ & $27,135,756.92$ \\
\hline Income per CFUG & $4,101.67$ & $30,257.19$ & $26,155.52$ \\
\hline Total expenditure & $3,537,797.00$ & $30,635,147.50$ & $27,097,350.50$ \\
\hline Expenditure per CFUG & $2,921.38$ & $28,873.84$ & $25,952.46$ \\
\hline Poor-focused expenditure & $95,948.00$ & $8,498,514.50$ & $8,402,566.50$ \\
\hline Poor-focused expenditure per CFUG & 79.23 & $8,009.91$ & $7,930.68$ \\
\hline Poor-focused expenditure, \% & $3 \%$ & $28 \%$ & $25 \%$ \\
\hline
\end{tabular}




\section{ISSUES AND IMPLICATIONS}

The discussion above pointed to the ways how the Maoist insurgency has been helpful in bringing about positive changes in several key areas. However, a host of issues pertaining to CF are especially pertinent to the post-conflict context. In this section, we discuss some of these issues and implications.

\section{Sustainability of Outcomes}

As discussed above, the Maoist conflict exerted a strong pressure and played a key role in enhancing innovations in Nepal's CF. However, it remains to be seen whether such innovations sustain through the post-conflict situation. It also raises the question of whether some conflict is necessary for innovations and change. Some other questions are equally important, such as whether all CFUGs are capable of or interested in sustaining the innovations, or whether the members of CFUG committees will be interested to continue them? Until now CFUGs have followed the practices introduced during the conflict, but it still raises concern on devising suitable support mechanisms to sustain the innovations and on policies and instruments to provide incentives for the CFUGs for the same.

\section{Tensions and Complementarities}

In the course of forestry interventions, development agents and rebels had complex relationship; they had tensions in some aspects and collaborated in others. While the Maoists were generally not positive to aid-funded development projects, they saw some of LFP's pro-poor strategies as compatible with their political goals. The LFP, however, did not proactively engage the Maoists in the development process. In few occasions in the course of the implementation of development actions, LFP staff had to face tough Maoist scrutiny and even restrictions. But once they came into dialogue, the Maoists allowed and even encouraged LFP activities. Thus, several pro-poor innovations were developed and implemented during the conflict period, directly benefiting the poorer households.
The rebels initially exerted stiff opposition to the processes of LFP's resource transfer and allocation. But once they were briefed about the process of development intervention, they accepted and allowed those processes. For instance, during the personnel hiring process facilitated by Samuhik Abhiyan (an NGO) in Bhojpur district, a Maoist area committee member initially pressured to select his afno manchhe (relatives) for the positions. When the LFP staffs opposed it and briefed him about the LFP's requirement of a transparent and accountable process, he became interested to participate in the selection committee. The subsequent results became acceptable for all persons, whether they were selected or not. The Maoists also liked the selection process and said that they would influence replicating such process in other areas.

\section{Relevance to the Post-conflict Situation}

Pro-poor innovations in CF provide an exemplary case for wider adoption across several development sectors. Due to their adaptation strategies, CFUGs were the only viable institutions which coordinated development activities in the rural areas during the conflict. In some cases, they worked as substitutes of the village development committees. Some line agencies even channelled their funds through CFUGs. However, this local capacity runs the risk of being undermined in the post-conflict situation and the CFUGs being reduced to deal with the forest management activities.

\section{Implications for State Restructuring}

In the post-conflict period, the role and strategies of development agencies and the CFUGs have changed. However, the local people developed their own capacity and adapted to the difficulties of the conflict. In doing so, there have been a strengthened civil society capacity at the grassroots level both to manage the local resources and to cope up with the difficulties. A broad awakening has emerged, and it places emphasis on the needs and rights of the poor 
and marginalised sections of community. Arguably, the CFUGs can play a role in negotiating rights in the state restructuring process, for which their networks and federations can bridge the national and local processes.

\section{CONCLUSION}

This paper presented the case of how the propoor development actions of LFP were conducted in interface with, and in the background of, Nepal's decade-long armed conflict. We argued that the Maoist conflict induced pressure for pro-poor change in the rules and practices of CFUGs. This added pressure for change that enhanced the impact of LFP's pro-poor development actions. The pressure empowered the voiceless and disadvantaged sections of the CFUGs. The access of the poor and excluded to resources and decision-making processes has also improved during the conflict. In adapting to the conflict, several pro-poor innovations were introduced at the CFUG level, and these have been subsequently incorporated in the CFUG constitutions and OPs.

While the Maoist conflict helped development actions to become more pro-poor, it does not follow that a violent conflict is necessary and desirable to the change process. Rather, the conflict can be seen as encouraging the emergence of some form of resistance from below, and this challenged the status quo and promoted development innovations. As the former rebels have been on the 'mainstream', the pressure from below has reduced considerably. In the Koshi Hills districts, the changes in CFUG norms and distributional practices have been significant, and these are likely to sustain over the long run. In order to attain the pro-poor objectives in post-conflict period, development actions need to pay heed to local resistance and to engage in political mobilisation of the poor and marginalised groups.

\section{REFERENCES}

Banjade, M. \& Timsina, N. 2005. Impact of Armed Conflict in Community Forestry of Nepal. ETFRN News, 43-44: 81-83.

Karki, A. \& Seddon, D. (Eds.) 2003. The People's War in Nepal: Left Perspectives. New Delhi: Adroit Publishers.

NPC 2007. Three-year Interim Plan (BS. 2064/65-2066/67). Nepali Text. Kathmandu: National Planning Commission.

Uprety, D.R. 2006. Conflicts in Natural Resource Management: Examples from Community Forestry. Available at: www.boku.ac.at/oega.

Kipat was a tenure system under which a community had rights over the land and resources located within its jurisdiction and it would allocate land and other resources to individuals for use under customary rules. 